\title{
Analisa Genotype dan Serotype Virus Hepatitis B Potensial sebagai Kandidat Sekuens Vaksin Hepatitis B secara Bioinformatika Berbasis Web
}

\author{
${ }^{1,3}$ Vanny Narita, ${ }^{1}$ Imam Rosyadi, ${ }^{2}$ Endang Ripmiatin \\ ${ }^{1}$ Program Studi Biologi, Fakultas Sains dan Teknologi, Universitas Al Azhar Indonesia, Kompleks Masjid \\ Agung Al Azhar, Jakarta Selatan, 12110, Indonesia \\ ${ }^{2}$ Program Studi Teknologi Informatika, Fakultas Sains dan Teknologi, Universitas Al Azhar Indonesia, \\ Kompleks Masjid Agung Al Azhar, Jakarta Selatan, 12110, Indonesia \\ ${ }^{3}$ Pusat Teknologi Farmasi dan Medika, Badan Pengkajian dan Penerapan Teknologi, Jl. MH Thamrin No. 8, \\ Gedung II BPPT, Lantai 15, Jakarta Pusat, 13340 \\ * Penulis untuk Korespondensi: vanny_narita@uai.ac.id
}

\begin{abstract}
Abstrak - Virus hepatitis B sudah menjadi masalah kesehatan publik terbesar ketiga dari populasi dunia yang dibuktikan dengan hasil serological infeksi kronis yang terjadi. Saat ini terdapat 10 jenis genotype virus hepatitis $B$, dari A hingga $\mathrm{J}$, dan 4 jenis serotype yaitu $a d w, a d r$, $a y w$, dan ayr. Penelitian ini bertujuan untuk menentukan genotype dan serotype virus hepatitis B yang memiliki potensi sebagai kandidat vaksin hepatitis $B$. Salah satu metode yang efektif saat ini adalah bioinformatika, suatu multidisplin ilmu biologi berbasis web yang dapat mengeksplorasi berbagai urutan dan melihat filogeni. Hasil penelitian menunjukkan bahwa data sekuens yang dapat menjadi kandidat untuk desain vaksin hepatitis B yaitu virus hepatitis B genotype B dengan subgenotype B3, genotype $\mathrm{C}$ dengan subgenotype $\mathrm{C} 6$ untuk lingkup Indonesia, sedangkan untuk lingkup dunia diperoleh potensi dari serotype Adw.
\end{abstract}

Abstrak - Hepatitis B virus has become the largest public health problem to three of the world's population as evidenced by the results of serological chronic infections that occur. In the world, there are 10 types of hepatitis $B$ virus genotypes present, from $A$ to $\mathrm{J}$, and 4 types of serotype, adw, adr, ayw, and ayr. In connection with various genotype and serotype, genotype and serotype candidate required potential so that the sequence can be used as a vaccine candidate sequence of hepatitis $B$. One of the effective methods currently is a web-based bioinformatics that could explore a variety of sequence and see the phylogeny, nor the annotations and predictions. Analysis of the sequence data predict can be candidate for the design of the hepatitis $B$ vaccine hepatitis $B$ virus genotype $B$ with subgenotype B3, subgenotype $\mathrm{C} 6$ from genotype $\mathrm{C}$ with scope for Indonesia, while tha scope of the world to obtain the potential of serotype adw.

Keywords - Hepatitis B, Bioinformatics, Genbank, Genotype, Serotype

\section{PENDAHULUAN}

$\mathrm{V}$ irus hepatitis B sudah menjadi masalah kesehatan publik terbesar ketiga dari populasi dunia yang dibuktikan dengan hasil serological infeksi kronis yang terjadi [1]. Hepatitis B menjadi masalah kesehatan dunia dengan lebih dari 350 juta orang terinfeksi kronis, beberapa di antaranya mengalami penyakit hati termasuk sirosis dan karsinoma [2]. Virus hepatitis B menjadi penyebab utama penyakit hati, termasuk di Asia [3].

Di dunia, saat ini terdapat 10 jenis genotype virus hepatitis $\mathrm{B}$, dari A hingga $\mathrm{H}$, ditambah dengan dua genotype I dan J dari Laos dan Jepang [3] dengan spesifikasi subgenotype yang telah diidentifikasi yaitu A ada 4 (A1-A4), B ada 8(B1-B8), C ada 7 (C1, C2, C3, C4, C5, C6, dan C7), D ada 6 (D1D6).

Terdapat sistem pengklasifikasian terbaru dengan sistem pembagian berdasar jenis HBsAg sebagai serologi utama, adw, adr, ayw, dan ayr [4]. Mulai 
ditemukan adanya korelasi antara HBsAg (antigen determinan virus hepatitis B) dengan genotype virus hepatitis B. Secara umum, individu yang memiliki genotype A, B, F, G, atau H merupakan subtype adw, genotype $\mathrm{C}$ termasuk adr, genotype $\mathrm{D}$ dan E merupakan subtype ayw.

Pada penelitian ini akan melihat potensi genotype dan serotype virus hepatitis B di Indonesia dan dunia secara bioinformatika berbasis web. Multidisiplin ilmu antara Bioinformatika (Biologi dan Informatika) dan Imunologi menghasilkan Ilmu Immunoinformatika yang dapat membantu untuk mendesain vaksin secara lengkap atau utuh. Setelah vaksin berhasil didesain, maka diperlukan validasi untuk menentukan apakah vaksin tersebut memiliki sekuens dan struktur yang serupa dengan protein/peptida asli [5].

Desain yang digunakan adalah mengetahui bagian epitope dari virus. Tahapan untuk mengetahui daerah epitope yaitu memprediksikan daerah conserved residues (daerah urutan asam amino yang $100 \%$ ada pada setiap tipe VHB) virus hepatitis $\mathrm{B}$, maka sekuen yang digunakan merupakan asam amino protein $\mathrm{S}$ VHB khusus isolasi di wilayah DKI Jakarta dengan nomor akses BAH84650.1. Kemudian memprediksi daerah conserved residues virus hepatitis $\mathrm{B}$ sebagai epitope dengan mempelajari dan mengkaji penelitian mengenai epitope virus hepatitis B. Jika data diprediksi tepat, maka selanjutnya dapat dilakukan eksperimen laboratorium.

\section{TINJAUAN PUSTAKA}

Virus hepatitis B secara mikrobiologi dikenal dengan taksonomi (10412) yaitu virus jenis retrotranscribing viruses, genus orthohepadnavirus, family Hepadnaviridae, yang termasuk kelompok grup VII (dsDNA-RT), spesies Hepatitis-B-type viruses. Virus dengan bentuk genom circular ini berukuran sekitar 3,2 kb, yang mengkode 7 protein. Protein tersebut yaitu protein $\mathrm{P}$ (polymerase), Capsid protein (C), External core antigen (c), Large S protein (S), pre-S1, pre-S2, dan protein X.

Setiap tujuh protein yang ada di dalam virus hepatitis B mempunyai fungsi spesifik masingmasing. Pertama, protein $\mathrm{P}$ (polymerase) dengan nama gen $\mathrm{P}$, mempunyai panjang sekuens 834 asam amino, berfungsi untuk menjadi bagian multienzim yang mengubah genom RNA virus ke dsDNA dalam sitoplasma capsid virus. Kedua, capsid protein $(\mathrm{HBcAg})$, dengan nama gen $\mathrm{c}$, mempunyai panjang sekuens 183 asam amino, berfungsi untuk mentransportasikan capsid sepanjang mikrotubulus ke nukleus. Ketiga, external core protein $(\mathrm{HBe} A g)$, nama gen $\mathrm{C}$, panjang sekuens 212 AA, berfungsi meregulasi respon imun ke dalam capsid intraselular. Keempat, Large S protein (L-HBsAg), dengan nama gen $\mathrm{S}$, panjang sekuens 389 asam amino, berfungsi dalam dua konformasi dari internal (Li-HBsAg) dan external (Le-HBsAg), konformasi internal berperan dalam pengaturan fungsi protein untuk morfogenesis virion dan mediasi kontak dengan nukleokapsid seperti protein matrix, sedangkan konformasi external, proteinnya akan menempelkan virus pada sel reseptor dan menginisiasi infeksi.

Adapun pada protein $S$ ada tiga jenis, large $S$ protein, kelima, medium $\mathrm{S}$ protein, dan keenam, small $S$ protein. Ketujuh, protein $X$, nama gen $X$, panjang sekuens 154 asam amino, protein yang fungsional, dapat memodulasi jalur degradasi protein, apoptosis, transkripsi, transduksi sinyal, progress siklus sel, dan stabilitas genetik secara langsung atau tak langsung yang berinteraksi dengan faktor inang.

Bioinformatika merupakan cabang ilmu biologi yang mencakup penggunaan teknologi komputasi untuk pengumpulan, penyimpanan, analisis, interpretasi, penyebaran dan aplikasi data-data biologi molekul. Perangkat utama Bioinformatika adalah software dan alamat-alamat website yang berfungsi sebagai database. Bioinformatika merupakan pengetahuan keterkaitan anatara analisa komputer dan data biologi. Suatu cakupan informasi yang tersimpan dalam bentuk kode genetik, hasil penelitian berbagai sumber, statistik pasien, dan literatur ilmiah [6].

Vaksinasi, riset immunologi molekuler, sebagai salah satu cabang dari biologi molekuler, telah berkembang pesat, telah juga dipatenkan dan hasil risetnya telah dipublikasi dalam banyak jurnal internasional per-reviewed. Pendekatan pengembangan vaksin menjadi dua bagian, yaitu metode konvensional, dan metode Bioinformatika. Metode konvensional mempunyai efek negatif lebih banyak dan butuh waktu yang sangat panjang untuk mengembangkannya.

Metode Bioinformatika, dalam pengembangannya dengan vaksin DNA yang dapat diolah dalam waktu lebih singkat. Hasil vaksin berbentuk rekombinan protein yang lebih aman dan efektif 
karena berasal dari antigen protein yang teratur dari sistem imunitas [7].

Sesuai dengan tujuan penelitian ini yaitu untuk mendesain vaksin hepatitis B berbasis epitop, pada pengembangan vaksin protein/peptida, diperlukan pengetahuan mengenai sekuens asam amino (epitop) yang memang memiliki impotensi besar untuk mengenerasi respon imun. Untuk mendeteksi sekuens asam amino yang berfungsi sebagai epitop, maka diperlukan bantuan komputer.

Untuk menentukan sekuens DNA apa yang dapat digunakan sebagai vaksin, diperlukan bantuan komputer. Informasi yang diberikan oleh aplikasi Imunoinformatika, dapat membantu untuk mendesain vaksin secara lengkap atau utuh. Setelah vaksin berhasil didesain, maka diperlukan validasi untuk menentukan apakah vaksin tersebut memiliki sekuens dan struktur yang serupa dengan protein/peptida asli. Jika sudah valid, maka dapat dilakukan eksperimen laboratoris untuk memproduksi vaksin tersebut [5].

\section{METODOLOGI PENELITIAN}

Hepatitis B virus memiliki 8 genotype, yang teridentifikasi di dunia saat ini yaitu genotype AH.Pada tingkat subgenotype, [2] hepatitis B virus memiliki 14 subgenotype yang telah teridentifikasi dari genotype A-D, yaitu 2 genotype A (A1 dan $\mathrm{A} 2), 5$ genotype $\mathrm{B}(\mathrm{B} 2, \mathrm{~B} 3, \mathrm{~B} 4, \mathrm{~B} 5, \mathrm{~B} 7$, dan satu subgenotype yang dalam penelitian $\mathrm{B} 8), 5$ subgenotype $\mathrm{C}(\mathrm{C} 1, \mathrm{C} 2, \mathrm{C} 5, \mathrm{C} 6$, dan $\mathrm{C} 7)$, serta 2 subgenotype D (D1 dan D3). Sedangkan terdapat tambahan subgenotype yang masih dipelajari yaitu B9 [3]. Pada penelitian ini difokuskan pada genotype dan subgenotype tertentu untuk mendapatkan hasil yang lebih spesifik.

Pada penelitian [8] menjelaskan bahwa adanya korelasi antara subtypes $\mathrm{HBsAg}$ (Hepatitis B surface Antigen) dan genotype Hepatitis B Virus. Secara umum, genotype Hepatitis B Virus A, B, F, $\mathrm{G}$, atau $\mathrm{H}$ memiliki subtype adw, Hepatitis B virus genotype $\mathrm{C}$ memiliki adr, dan Hepatitis $\mathrm{B}$ virus genotype $\mathrm{D}$ dan $\mathrm{E}$ memiliki subtype ayw. Hasil penelitian menunjukkan bahwa genotype pertama yang predominan di Indonesia adalah B dengan jumlah kasus yang diketahui 594 (66\%), kedua genotype C sejumlah 214 kasus (24\%). Ketiga genotype $\mathrm{D}$ dengan jumlah 61 (7\%), genotype $\mathrm{A}$ sebanyak $4(0,4 \%)$. Sama halnya dengan penelitian [3] menjelaskan bahwa genotype B menjadi yang terbanyak 74.6\% (141 isolate), diikuti genotype C sebesar $25.4 \%$ (48 isolate).

Oleh karena itu, fokus penelitian ini untuk sekuens Indonesia dengan genotype B yang menjadi predominan dan genotype $\mathrm{C}$ yang menjadi kedua terbesar di Indonesia. Berdasarkan data [9][10][11][12] dari 28 kota di Indonesia yang menjadi sampel diperoleh pada tingkat subgenotype B yang terbanyak berjumlah 428 kasus $(70 \%)$ adalah subgenotype B3, serta data statistik menunjukkan keunikan pada genotype C pada C6 yaitu memiliki pandemik di wilayah Indonesia timur atau papua terbanyak, sebesar 33 kasus (14\%). Gambar 1 menunjukkan alur Bioinformatka dengan analisa COBRA.

Tahap pertama yaitu pengumpulan dan seleksi sekuens DNA nucleotide atau asam amino virus hepatitis B. Seluruh data sekuens DNA nucleotide dan asam amino virus hepatitis B dengan genotype dan serotype target diakses dan dikumpulkan dari genbank (http://www.ncbi.nlm.nih.gov/) [4]. Seleksi sekuens DNA nucleotide dan asam amino dipilih dengan kriteria merupakan sekuens terdapat CDS gen $\mathrm{S}$ sesuai dengan target antigen HBsAg.

Tahap kedua, pembuatan pohon kekerabatan. Pohon kekerabatan ini didesain dengan multiple alignment, phylogeny, dan tree viewers menggunakan phylogeny.fr (http://www.phylogeny.fr/) [10]. Pohon kekerabatan dibuat berdasarkan dua jenis, yaitu berbasis sekuens DNA nucleotide dan protein. Keduanya akan dibandingkan dan dilihat kesamaan dalam kekerabatannya.

\begin{tabular}{l}
$\begin{array}{c}\text { Sekuen nukleotida Hepatitis B Virus diunduh pada } \\
\text { Genbank NCBI Hepatitis Virus }\end{array}$ \\
\hline Sekuen nukleotida \\
\hline Sekuen protein (kode genetik standar) \\
\hline Sekuen dikelompokkan berdasarkan filogeni \\
\hline $\begin{array}{c}\text { Sekuen dibagi menjadi grup kejadian luar biasa } \\
\text { (KLB) berdasarkan lokasi dan waktu }\end{array}$ \\
$\begin{array}{c}\text { Primary Consensus Sequence: Multiple alignment } \\
\text { di satu grup KLB menggunakan AlignX (Vektor } \\
\text { NTI) }\end{array}$ \\
$\begin{array}{c}\text { Secondary Consensus Sequence: } \text { Multiple alignment } \\
\text { tiap subclade virus }\end{array}$ \\
\hline $\begin{array}{c}\text { Final Consensus Sequence: Hasil multiple } \\
\text { alignment }\end{array}$ \\
COBRA (Computationally Optimized Broadly \\
Reactive Antigen)
\end{tabular}

Gambar 1. Alur Bioinformatika dengan Analisis COBRA [2] 


\section{HASIL DAN PEMBAHASAN}

Berdasarkan penelitian ini, diperoleh dua data utama dalam sekuens yang potensial sebagai kandidat vaksin hepatitis $B$ (Tabel 1 dan 2). Pertama, dilihat dari sisi Indonesia bahwa virus hepatitis B yang memiliki penyebaran tertinggi yaitu B3 dan penyebaran tertinggi di daerah timur Indonesia yaitu C6. Kedua, dari sisi keseluruhan sekuens Indonesia yang sifatnya sekuens complete genome diperoleh data terdapat 65 sekuens complete genome virus hepatitis B yang diperoleh dari ncbi.nlm.nih.gov.

Berikut merupakan nomor akses dari ke 65 complete genome $H B V$ Indonesia $\mathrm{ADB} 03543.1$, ADB03533.1, $\quad$ ADB03523.1, $\quad$ ADB03514.1, ADB03504.1, ADB03494.1, ADB03484.1, ADB03475.1, $\quad$ ADB03465.1, $\quad$ ADB03459.1, ADB03450.1, $\quad$ ADB03440.1, $\quad$ ADB03538.1, ADB03528.1, $\quad$ ADB03518.1, $\quad$ ADB03509.1, ADB03499.1, $\quad$ ADB03489.1, $\quad$ ADB03480.1, ADB03470.1, ADB03461.1, ADB03452.1, ADB03445.1, $\quad$ ADB03435.1, $\quad$ BAJ33455.1, BAJ33451.1, BAJ06642.1, BAJ06634.1, BAJ06646.1, $\quad$ BAJ06638.1, $\quad$ ACH47043.1,
ACH47038.1, $\quad$ AAA45482.1, $\quad$ BAH84742.1, BAH84734.1, BAH84726.1, BAH84718.1, BAH84710.1, $\quad$ BAH84702.1, $\quad$ BAH84694.1, BAH84686.1, $\quad$ BAH84678.1, BAH84670.1, BAH84662.1, $\quad$ BAH84654.1, BAH84646.1, BAH84738.1, $\quad$ BAH84730.1, $\quad$ BAH84722.1, BAH84714.1, $\quad$ BAH84706.1, BAH84698.1, BAH84690.1, BAH84682.1, BAH84674.1, BAH84666.1, BAH84658.1, BAH84650.1, ABS50174.1, ABS50180.1, ABS50141.1, ABS50167.1, ABS50153.1, ABS50147.1, ABS50160.1.

Adapun hasil pohon kekerabatan 65 complete genome virus hepatitis B Indonesia berbasis protein dapat dilihat pada Gambar 2.

Berdasarkan hasil analisis radial phylogeny.fr dari 65 complete genome HBV Indonesia ditemukan 3 genotype utama yaitu genotype B, C dan D. Jumlah Genotype D lebih sedikit dibandingkan gnotype C dan genotype D. Langkah selanjutnya adalah menentukan daerah conserved residu yang merupakan langkah selanjutnya untuk memprediksi epitope pada virus HBV Indonesia.

Tabel 1. Data sekuen DNA nucleotide dan protein subgenotype B3 subtype Adr

\begin{tabular}{|c|c|c|c|c|c|c|}
\hline No. & Uniprot & $\begin{array}{c}\text { GenBank } \\
\text { DNA } \\
\end{array}$ & $\begin{array}{c}\text { GenBank } \\
\text { Protein } \\
\end{array}$ & Isolate & Waktu & Lokasi \\
\hline 1 & F4Y822 & GU071379 & ADQ42872 & EIB181 & Nov-07 & Indonesia \\
\hline 2 & F4Y821 & GU071378 & ADQ42871.1 & EIBI68 & Sep-07 & Indonesia \\
\hline 3 & F4Y818 & GU071375 & ADQ42868 & EIB87 & Juni 2006 & Indonesia \\
\hline 4 & F4Y816 & GU071373 & ADQ42866 & EIB84 & Juni 2006 & Indonesia \\
\hline 5 & F4Y831 & GU071388 & ADQ42881.1 & EIH163 & Sep-07 & Indonesia \\
\hline 6 & F4Y7T2 & GU071283 & ADQ42782.1 & ALO178 & Agustus 2005 & Alor, Indonesia \\
\hline 7 & F4Y7T6 & GU071287 & ADQ42786.1 & ALO12 & Agustus 2005 & Alor, Indonesia \\
\hline 8 & F4Y7T4 & GU071285 & ADQ42784.1 & ALO09 & Agustus 2005 & Alor, Indonesia \\
\hline 9 & F4Y7Z2 & GU071347 & ADQ42842.1 & LIOT17 & Agustus 2005 & Flores, Indonesia \\
\hline 10 & F4Y8M6 & GU071626 & ADQ43076.1 & 28004 & 1998 & Lombok, Indonesia \\
\hline 11 & F4Y8M7 & GU071627 & ADQ43077.1 & 28006 & 1998 & Lombok, Indonesia \\
\hline 12 & F4Y8M8 & GU071628 & ADQ43078.1 & 28041 & 1998 & Lombok, Indonesia \\
\hline 13 & F4Y8M3 & GU071623 & ADQ43073.1 & 2233 & 1998 & Lombok, Indonesia \\
\hline 14 & F4Y8L6 & GU071615 & ADQ43066.1 & 2038 & 1998 & Lombok, Indonesia \\
\hline 15 & F4Y8L7 & GU071616 & ADQ43067.1 & 2040 & 1998 & Lombok, Indonesia \\
\hline 16 & F4Y8L8 & GU071617 & ADQ43068.1 & 2041 & 1998 & Lombok, Indonesia \\
\hline 17 & F4Y8L5 & GU071613 & ADQ43065.1 & 28048 & 1998 & Lombok, Indonesia \\
\hline 18 & F4Y8D3 & GU071516 & ADQ42983.1 & MR6 & 2001 & Sulawesi, Indonesia \\
\hline
\end{tabular}




\begin{tabular}{|c|c|c|c|c|c|c|}
\hline No. & Uniprot & $\begin{array}{c}\text { GenBank } \\
\text { DNA }\end{array}$ & $\begin{array}{c}\text { GenBank } \\
\text { Protein }\end{array}$ & Isolate & Waktu & Lokasi \\
\hline 19 & F4Y8D4 & GU071517 & ADQ42984.1 & MR35 & 2001 & Sulawesi, Indonesia \\
\hline 20 & F4Y8D7 & GU071520 & ADQ42987.1 & MR123 & 2001 & Sulawesi, Indonesia \\
\hline 21 & F4Y8D9 & GU071522 & ADQ42989.1 & MR145 & 2001 & Sulawesi, Indonesia \\
\hline 22 & F4Y8D2 & GU071515 & ADQ42982.1 & MR183 & 2001 & Sulawesi, Indonesia \\
\hline 23 & F4Y869 & GU071433 & ADQ42919.1 & Kjg008 & 2001 & Sulawesi, Indonesia \\
\hline 24 & F4Y895 & GU071459 & ADQ42945.1 & Mks153 & 2001 & Sulawesi, Indonesia \\
\hline 25 & F4Y8E6 & GU071529 & ADQ42996.1 & Mtw111 & 2005 & Mentawai, Indonesia \\
\hline 26 & F4Y896 & GU071460 & ADQ42946.1 & EIHBPL05 & Maret 2008 & Sumatra, Indonesia \\
\hline 27 & F4Y898 & GU071462 & ADQ42948.1 & EIHBPL06 & Maret 2008 & Sumatra, Indonesia \\
\hline 28 & F4Y899 & GU071463 & ADQ42949.1 & EIHBPL07 & Maret 2008 & Sumatra, Indonesia \\
\hline 29 & F4Y8A0 & GU071467 & ADQ42950.1 & EIHBPL12 & Maret 2008 & Sumatra, Indonesia \\
\hline 30 & F4Y8A2 & GU071472 & ADQ42952.1 & EIHBPL18 & Maret 2008 & Sumatra, Indonesia \\
\hline 31 & F4Y8A3 & GU071473 & ADQ42953.1 & EIHBPL20 & Maret 2008 & Sumatra, Indonesia \\
\hline 32 & F4Y8A5 & GU071476 & ADQ42955.1 & EIHBPL25 & Maret 2008 & Sumatra, Indonesia \\
\hline 33 & F4Y8A6 & GU071478 & ADQ42956.1 & EIHBPL29 & Maret 2008 & Sumatra, Indonesia \\
\hline 34 & F4Y8A7 & GU071479 & ADQ42957.1 & EIHBPL30 & Maret 2008 & Sumatra, Indonesia \\
\hline 35 & F4Y8A8 & GU071480 & ADQ42958.1 & EIHBPL31 & Maret 2008 & Sumatra, Indonesia \\
\hline 36 & F4Y8A9 & GU071481 & ADQ42959.1 & EIHBPL35 & Maret 2008 & Sumatra, Indonesia \\
\hline 37 & F4Y8B1 & GU071484 & ADQ42961.1 & EIHBPL43 & Maret 2008 & Sumatra, Indonesia \\
\hline 38 & F4Y8B2 & GU071486 & ADQ42962.1 & EIHBPL52 & Maret 2008 & Sumatra, Indonesia \\
\hline 39 & F4Y8B3 & GU071487 & ADQ42963.1 & EIHBPL59 & Maret 2008 & Sumatra, Indonesia \\
\hline 40 & F4Y8A8 & GU071480 & ADQ42958.1 & EIHBPL31 & Maret 2008 & Sumatra, Indonesia \\
\hline 41 & F4Y8A9 & GU071481 & ADQ42959.1 & EIHBPL35 & Maret 2008 & Sumatra, Indonesia \\
\hline 42 & F4Y8B0 & GU071483 & ADQ42960.1 & EIHBPL41 & Maret 2008 & Sumatra, Indonesia \\
\hline 43 & F4Y8B1 & GU071484 & ADQ42961.1 & EIHBPL43 & Maret 2008 & Sumatra, Indonesia \\
\hline 44 & F4Y8B2 & GU071486 & ADQ42962.1 & EIHBPL52 & Maret 2008 & Sumatra, Indonesia \\
\hline 45 & F4Y8B3 & GU071487 & ADQ42963.1 & EIHBPL59 & Maret 2008 & Sumatra, Indonesia \\
\hline 46 & F4Y8B4 & GU071489 & ADQ42964.1 & EIHBPL70 & Maret 2008 & Sumatra, Indonesia \\
\hline 47 & F4Y8B5 & GU071492 & ADQ42965.1 & EIHBPL77 & Maret 2008 & Sumatra, Indonesia \\
\hline 48 & F4Y8B6 & GU071494 & ADQ42966.1 & EIHBPL85 & Maret 2008 & Sumatra, Indonesia \\
\hline 49 & F4Y8B7 & GU071495 & ADQ42967.1 & EIHBPL86 & Maret 2008 & Sumatra, Indonesia \\
\hline 50 & F4Y8B8 & GU071496 & ADQ42968.1 & EIHBPL88 & Maret 2008 & Sumatra, Indonesia \\
\hline
\end{tabular}


Tabel 2. Data sequence DNA nucleotide dan protein genotype $\mathrm{C}$ subtype Adw

\begin{tabular}{|c|c|c|c|c|c|c|}
\hline No. & Genotype & GenBank Protein & GenBank DNA & Waktu & Isolate & Lokasi \\
\hline 1 & C6 & ADB03523.1 & GQ358155.1 & Nov-07 & J022 & Indonesia \\
\hline 2 & $\mathrm{C}$ & BAJ51607.1 & AB554015.1 & 28-Dec-10 & TRF08111 & Indonesia:Papua \\
\hline 3 & $\mathrm{C}$ & BAJ51603.1 & AB554014.1 & 28-Dec-10 & TRF08029 & Indonesia:Papua \\
\hline 4 & $\mathrm{C}$ & BAH84722.1 & AP011103.1 & 8-Jul-09 & & Indonesia:Jayapura \\
\hline 5 & $\mathrm{C}$ & BAJ51635.1 & AB554022.1 & 28-Dec-10 & GRS08325 & Indonesia:Papua \\
\hline 6 & $\mathrm{C}$ & BAJ51631.1 & AB554021.1 & 28-Dec-10 & GRS08298 & Indonesia:Papua \\
\hline 7 & $\mathrm{C}$ & BAH84718.1 & AP011102.1 & 8-Jul-09 & human serum & Indonesia:Biak \\
\hline 8 & C6 & ADB03533.1 & GQ358157.1 & Nov-07 & M007 & Indonesia \\
\hline 9 & $\mathrm{C}$ & BAJ51619.1 & AB554018.1 & 28-Dec-10 & NMB09075 & Indonesia:Papua \\
\hline 10 & $\mathrm{C}$ & BAJ33451.1 & AB560661.1 & 15-Sep-06 & $58 \mathrm{PU}$ & Indonesia:Papua \\
\hline 11 & $\mathrm{C}$ & BAL03304.1 & AB644281.1 & 17-Feb-12 & NAB9 & Indonesia:Papua \\
\hline 12 & $\mathrm{C}$ & BAJ06646.1 & AB540585.1 & 7-May-10 & human serum & East Nusa Tenggara \\
\hline 13 & $\mathrm{C} 6$ & ADB03528.1 & GQ358156.1 & Nov-07 & STN013 & Indonesia \\
\hline 14 & $\mathrm{C}$ & BAH84702.1 & AP011098.1 & 8-Jul-09 & human serum & Waikabubak \\
\hline 15 & $\mathrm{C}$ & BAJ51647.1 & AB554025.1 & 28-Dec-10 & MRK89073 & Indonesia:Papua \\
\hline 16 & $\mathrm{C}$ & BAJ33455.1 & AB560662.1 & 15-Sep-06 & $60 \mathrm{PU}$ & Indonesia:Papua \\
\hline 17 & $\mathrm{C} 6$ & ADQ43050.1 & GU071596.1 & Sep-07 & STN013 & Indonesia:Papua \\
\hline 18 & C6 & ADQ43057.1 & GU071603.1 & Sep-07 & $\mathrm{J} 121$ & Indonesia:Papua \\
\hline 19 & C6 & ADQ43058.1 & GU071604.1 & Oct-07 & $\mathrm{J} 141$ & Indonesia:Papua \\
\hline 20 & $\mathrm{C} 6$ & ADQ43061.1 & GU071607.1 & Sep-07 & M007 & Indonesia:Papua \\
\hline 21 & $\mathrm{C}$ & ACH71390.1 & EU926212.1 & 22-May-07 & 22.175 .07 & Indonesia \\
\hline 22 & $\mathrm{C}$ & ACH71371.1 & EU926202.1 & 16-Feb-07 & 22.015 .07 & Indonesia \\
\hline 23 & $\mathrm{C}$ & ACH71378.1 & EU926206.1 & 11-Mar-07 & 22.080 .07 & Indonesia \\
\hline 24 & $\mathrm{C}$ & ACH71376.1 & EU926205.1 & 10-Mar-07 & 22.076 .07 & Indonesia \\
\hline 25 & $\mathrm{C}$ & ACH71369.1 & EU926201.1 & 14-Feb-07 & 22.004 .07 & Indonesia \\
\hline 26 & $\mathrm{C}$ & ACH71380.1 & EU926207.1 & 26-Apr-07 & 22.142 .07 & Indonesia \\
\hline 27 & $\mathrm{C}$ & BAJ51723.1 & AB554063.1 & 28-Dec-10 & EGR09139 & Indonesia:Papua \\
\hline 28 & $\mathrm{C} 6$ & ADQ43060.1 & GU071606.1 & Sep-07 & J022 & Indonesia: Papua \\
\hline 29 & C6 & ADQ43055.1 & GU071601.1 & Sep-07 & J043 & Indonesia: Papua \\
\hline 30 & $\mathrm{C}$ & BAJ51709.1 & AB554056.1 & 28-Dec-10 & GRS08458 & Indonesia: Papua \\
\hline
\end{tabular}




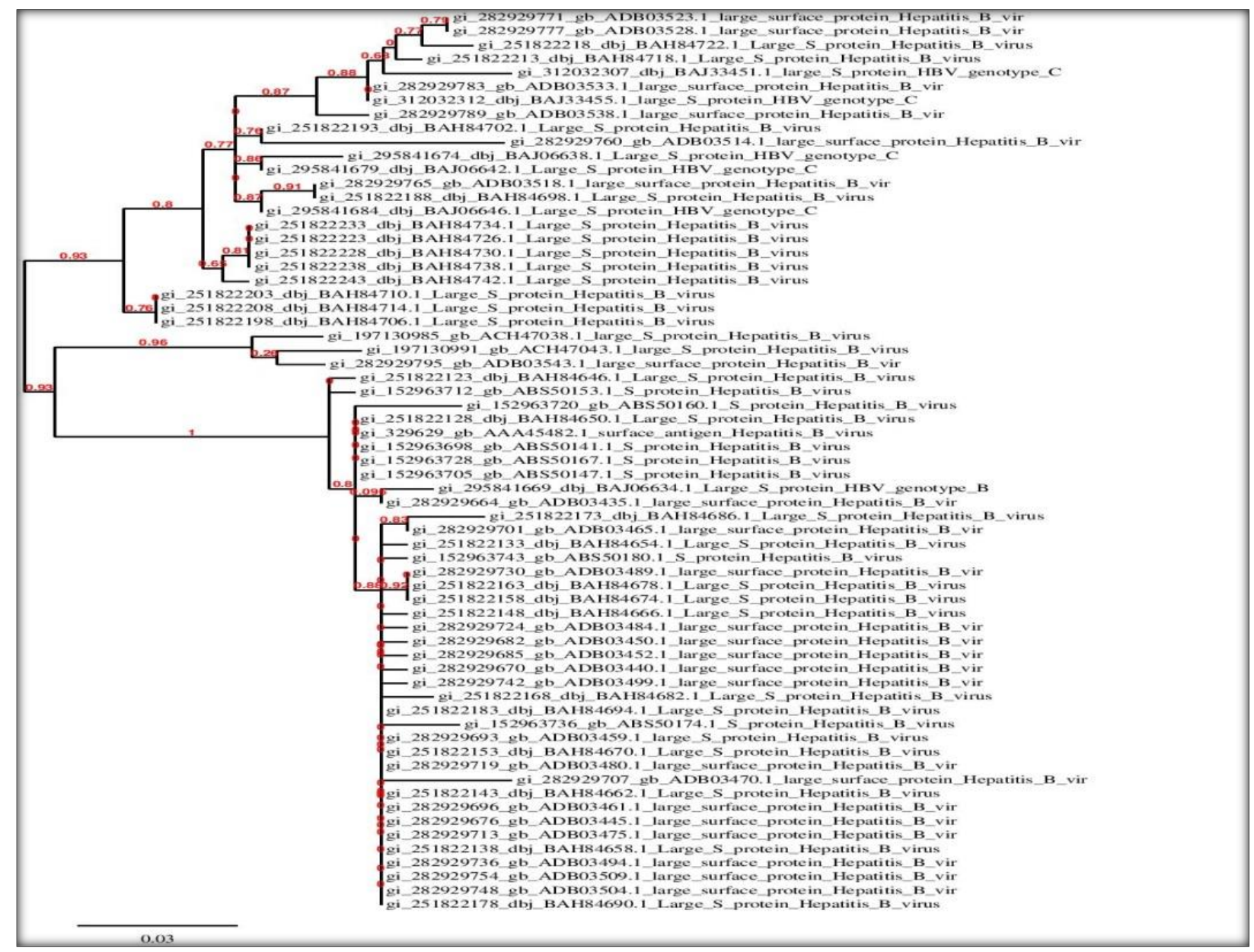

Gambar 2. Pohon kekerabatan 65 complete genome virus hepatitis B Indonesia berbasis protein

Dari 64 sekuens DNA nucleotide yang terdaftar sebagai virus hepatitis B subtype adw pada genbank, diperoleh 43 sekuens yang sesuai kriteria. 43 sekuens yang terpilih mempunyai nomor accession genbank sebagai berikut:

JN406371.1, AY220697.1, AY220698.1, AB033555.1, U87742.3, GU357842.1,
M57663.2,

AF461360.1,

AY220703.1, AY128092.1, HM153811.1, HM117850.2, GU357844.1,
AY220704.1, AB033554.1, AY518556.1, HM117851.2, AY934771.1,
AY934769.1,
AY934767.1,
AY934765.1, AY934774.1, AY934766.1, AF462041.1, X98077.1, AB059660.1, AB033552.1, X97851.1, AY934770.1, AF282918.1, M54923.1, AB059661.1, AB033553.1, AB033556.1, AY934768.1, AF282917.1, EU350409.1, AB059659.1, AB033551.1, AB033557.1, X97850.1, dan X51970.1.

Adapun hasil pembuatan pohon kekerabatan virus hepatitis B subtype adw, dapat dilihat pada Gambar 3. 


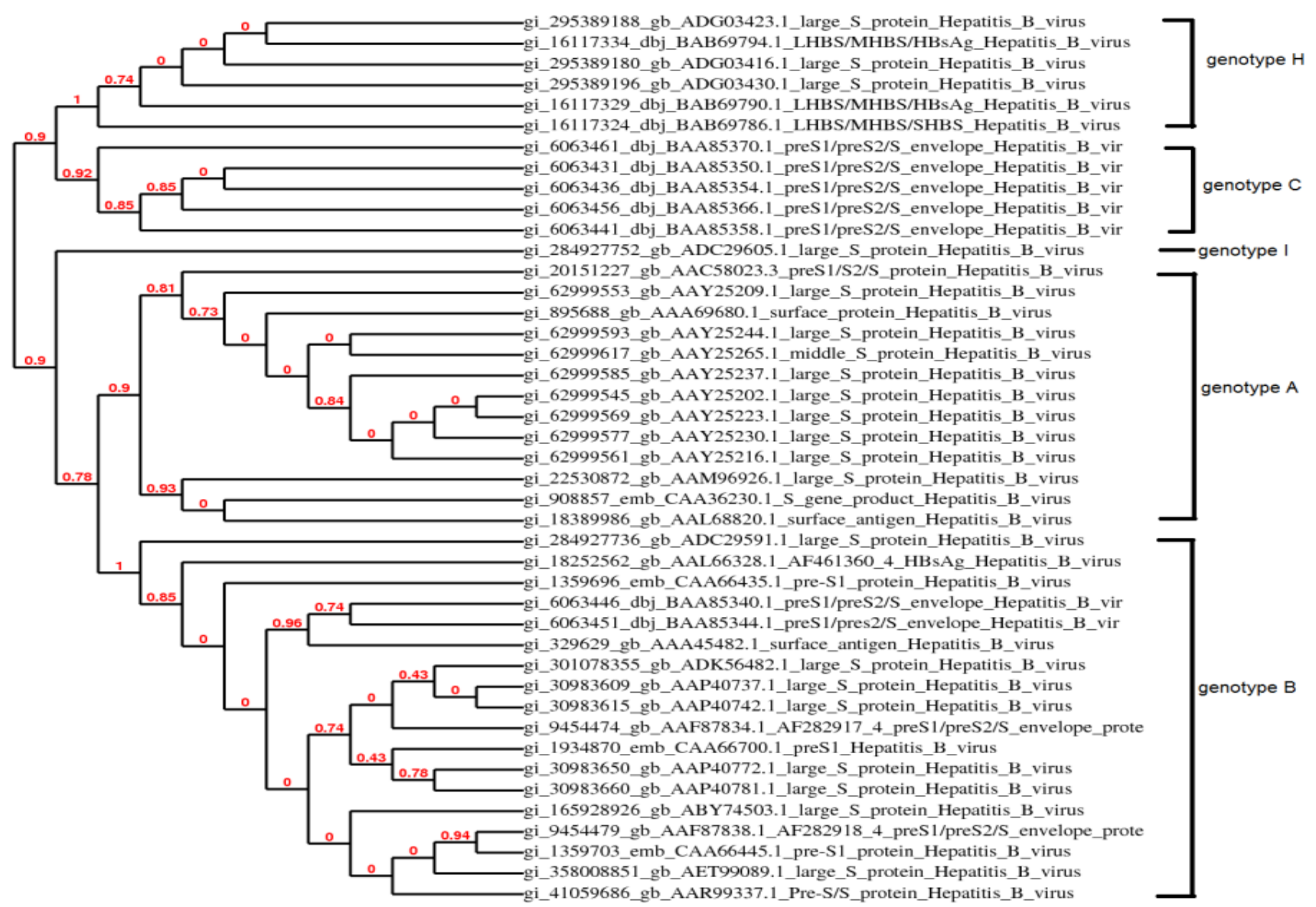

Gambar 3. Pohon kekerabatan virus hepatitis B subtype adw di dunia berbasis protein

Berdasarkan hasil multiple sequence alignment yang disesuaikan dengan parameter dari phylogeny.fr menunjukkan bahwa dari 43 sekuens DNA posisi yang terseleksi 846 posisi, dengan nilai $70 \%$ asli dari 1206 posisi. Sedangkan dari 43 sekuens protein terpilih posisi 281 dengan nilai $70 \%$ asli dari 401 posisi. Adapun sekuens DNA dan protein sama dalam hal nilai parameter dengan conserved position sebanyak 22 sekuens, dan terdapat dua sekuens yang menyamping.

Data yang diperoleh menunjukkan bahwa terdapat 43 sekuens dengan subtype yang sama yaitu Adw, namun genotype dan distribusi penyebaran virus hepatitis B yang berbeda. Genotype A berasal dari Somalia (Afrika), dan Filipina (Asia), genotype B berasal dari Indonesia dan China, sesuai dengan penelitian [9] dan [13] bahwa genotype B terdapat di Indonesia dan China. Genotype C tidak terdapat informasi dari sekuens namun [11][12][13][1], menjelaskan bahwa genotype $\mathrm{C}$ terdapat di sekitar Asia Selatan dan Asia Timur, genotype $\mathrm{H}$ diperoleh informasi berasal dari Amerika dan
Meksiko [14], dan genotype I berasal dari China [15].

Berdasarkan hasil analisis data ini, dapat menjadi informasi terbaru yaitu genotype I termasuk dalam subtype adw, bersesuaian dengan informasi dari [16][8][14] bahwa subtype adw meliputi A, B, F, G, H, dan I.

\section{KESIMPULAN}

Berdasarkan penelitian ini diperoleh data sekuens yang dapat menjadi kandidat untuk desain vaksin hepatitis B yaitu virus hepatitis B genotype B dengan subgenotype $\mathrm{B} 3$, genotype $\mathrm{C}$ dengan subgenotype C6 untuk lingkup Indonesia, sedangkan untuk lingkup dunia diperoleh potensi dari serotype Adw. 


\section{UCAPAN TERIMA KASIH}

Penulis mengucapkan terima kasih kepada Lembaga Penelitian dan Pengabdian Masyarakat Universitas Al Azhar Indonesia atas Grant LP2M TA 2011-2012.

\section{DAFTAR PUSTAKA}

[1] Massoumi, H., et al., (2011). Management of chronic hepatitis B. Eur J Gastroenterol Hepatol. 23(8):642-50.

[2] Mulyanto et al., (2009), A nationwide molecular epidemiological study on hepatitis B virus in Indonesia: identification of two novel subgenotypes, B8 and C7. Arch Virol. 154(7):1047-59.

[3] Thedja, M.D., et al., (2011). Ethnogeographical structure of hepatitis B virus genotype distribution in Indonesia and discovery of a new subgenotype, B9. Arch Virol. 156(5):855-68.

[4] Mulyanto et al., (2011). Analysis of the full-length genomes of novel hepatitis B virus subgenotyoes $\mathrm{C} 11$ and $\mathrm{C} 12$ in Papua, Indonesia. J Med Virol. 83(1):54-64.

[5] Sollner, J., et al. (2010). Concept and application of a computational vaccinology workflow. Immunome Research. 6 (Suppl 2) 57.

[6] Nilges, M. \& Linge, J.P., (2011). Bioinformatika: a definition. Unite de Bio-Informatique Structurale, Institut Pasteur, 25-28 rue du Docteur Roux, F75015 Paris, France.

[7] Rappuoli, R. (2000). Reverse vaccinology. Curr Opin Microbiol. 3:445-450.

[8] Kurbanov et al., (2008). When should "I" consider a new hepatitis B virus genotype? J Virol. 82(16):8241-2.

[9] http://www.ncbi.nlm.nih.gov/

[10] http://www.phylogeny.fr/

[11] Huy, T.T., et al., (2004). Genotype C of hepatitis $B$ virus can be classified into at least two subgroups. J Gen Virol. 85(Pt 2):283-92.

[12]Lusida et al., (2008). Novel subgenotypes of hepatitis B virus genotypes C and D in Papua, Indonesia. J Clin Microbiol. 46(7):2160-6.

[13] Juniastuti, et al., (2011). Another novel subgenotype of hepatitis $\mathrm{B}$ virus genotype $\mathrm{C}$ from papuans of Highland origin. J Med Virol 83(2):225-34.

[14] Panduro, A., et al., (2013). Distribution of HBV genotypes $\mathrm{F}$ and $\mathrm{H}$ in Mexico and Central America. Antivir Ther. 18(3 Pt B):475-84.

[15] Yu, H., et al., (2010). Molecular and phylogenetic analyses suggest an additional hepatitis B virus genotype "I". PLoS One. 5(2):e9297.

[16] Kramvis, A., et al., (2008). Relationship of serological subtype, basic core promoter and precore mutations to genotypes/subgenotypes of hepatitis B virus. J Med Virol. 80(1):27-46. 